Original Article

\title{
Evaluation of Response of Parenteral Dexamethasone in Pemphigus Vulgaris
}

\author{
Jamal Uddin $\mathrm{M}^{1}$, Maidul $A Z M \mathrm{I}^{2}$, Eakub $M \mathrm{~A}^{3}$, Wahab $M A^{4}$, Khondker $\mathrm{L}^{5}$ \\ Abstract
}

A clinical trial was carried out in the Department of Dermatology and Venereology, Bangabandhu Sheikh Mujib Medical University, Dhaka. The total number of patients was thirty and among them fifteen patients were treated with injection dexamethasone (Group-A) and other fifteen were treated with oral prednisolone (Group-B). The study showed that in Group-A, on admission and after 6 weeks, the mean number $( \pm S D)$ of skin lesion of pemphigus was $36.87 \pm 8.40$ and $5.27 \pm 1.624$ respectively. In Group-B, on admission and after 6 weeks, the mean number $( \pm S D)$ of skin lesion of pemphigus was $36.27 \pm 8.980$ and $7.73 \pm 1.007$ respectively. The study also observed that in group-A, on admission and after 6 weeks, the mean number $( \pm S D)$ of mucous membrane lesion of pemphigus was $3.40 \pm 2.633$ and $1.00 \pm 0.926$ respectively. In Group-B, on admission and after 6 weeks, the mean number $( \pm S D)$ of mucous membrane lesion of pemphigus was $3.33 \pm 2.225$ and $1.87 \pm 1.246$ respectively. Statistically significant improvement was observed in both groups in all clinical parameter after 6 weeks. Dexamethasone group showed statistically higher significant improvement than prednisolone group in all clinical parameter except Nikolsky's sign. Injection dexamethasone appears to be more effective than oral prednisolone in early management of pemphigus vulgaris.

$>\quad$ CBMJ 2013 July: Vol. 02 No. 02 P: 25-29

Key words: Parenteral dexamethasone therapy, pemphigus vulgaris.

\section{Introduction}

The term pemphigus refers to a group of autoimmune blistering disease of skin and mucous membranes which is characterized histologically by intraepidermal blisters due to acantholysis (i.e, separation of epidermal cells from each other) and immunopathologically by in vivo bound and circulating IgG directed against the cell surface of keratinocytes. About $0.8 \%$ of all dermatologic patients suffer from pemphigus ${ }^{2}$. Pemphigus vulgaris (PV) is the most common type of pemphigus and comprises about $80 \%$ of patients with pemphigus ${ }^{1}$. The prevalence of pemphigus vulgaris is about equal in men and women. The mean age of onset is fourth to sixth decades. But it may be seen in children and the elderly ${ }^{3}$. There is strong genetic background to pemphigus vulgaris and there is also HLA association in pemphigus vulgaris. Most patients are of HLA phenotype DR4 or DR6 ${ }^{2}$. In about $50-70 \%$ of the cases the disease begins with oral lesion, which may precede the cutaneous lesions by several months. Cutaneous lesions can be localized or generalized and usually present primarily as flaccid vesicles or bullae varying in size from less than $1 \mathrm{~cm}$ to several centimeter.

1. *Dr. Mohammad Jamal Uddin, Assistant Professor, Department of Dermatology and Venereology, Bangabandhu Sheikh Mujib Medical University Shahbag, Dhaka, Bangladesh.

2. Prof. Dr. A. Z. M Maidul Islam, Former Chairman, Department of Dermatology and Venereology, Bangabandhu Sheikh Mujib Medical University Shahbag, Dhaka, Bangladesh.

3. Dr. Mohammad Eakub Ali, Professor, Department of Dermatology and Venereology, Bangabandhu Sheikh Mujib Medical University.Shahbag, Dhaka, Bangladesh.

4. Lt Col (Retd) Dr. Md Abdul Wahab, Department of Dermatology and Venereology, Bangabandhu Sheikh Mujib Medical University, Shahbag, Dhaka, Bangladesh.

5. Dr. Lubna Khondker, Assistant Professor, Department of Dermatology and Venereology Bangabandhu Sheikh Mujib Medical University Shahbag, Dhaka, Bangladesh.

*Address of Correspondence: Mobile- 01819225300

E-mail: jamalbsmmu@yahoo.com 
The scalp, pre-sternal, genitals, axillae and groin are frequent sites of involvement. The blisters rupture easily and produce painful raw denuded areas ${ }^{4}$. The Nikolsky's sign is present. There is an absence of cohesion in the epidermis, so the upper layers of the epidermis may easily be removed by a twisting pressure with the fingertip, leaving a moist surface. The bulla spreading phenomena can be tested by pressure on an intact bulla, gently forcing lead the fluid to wander under the skin away from site ${ }^{3}$. Pemphigus vulgaris is associated with high morbidity as well as significant mortality rate, before the advent of systemic corticosteroid therapy in 1950s. The mortality rate was reported $70 \%$ to $100 \%$ at that time. The use of corticosteroid dramatically reduced the death rate from this to a mean of $30 \%{ }^{5}$. The course of pemphigus vulgaris is almost chronic. Today the risk of death in pemphigus from the side effect of oral prednisolone is greater than risk of death from the disease itself. Death from sepsis and other complications of therapy occurs in 5\% to $10 \%$ of treated cases. Untreated disease is usually fatal ${ }^{6}$. To minimize the cumulative steroid affects in pemphigus, there has been a continuous search for alternative therapies concerning treatment of this disease. Pulse therapy, the 'big shot', refers to discontinuous intravenous infusion of very high-dose corticosteroid over a short period. Due to lack of available monitoring facility after giving so large dose of steroid, we intended to use $5 \mathrm{mg}$ of dexamethasone intravenously eight hourly for early control of disease. It is evident that no trial with dexamethasone has been yet done in Bangladesh. Since there is no recorded study in Bangladesh, this study was undertaken to find out the efficacy of parenteral dexamethasone compared with oral prednisolone in early management of pemphigus vulgaris.

\section{Methods}

A clinical trial was conducted in the department of Dermatology and Venereology, Bangabandhu Sheikh Mujib Medical University, Dhaka. The period of study was from January 2004 to June 2005. The total number of patients was thirty. Among them 15 patients were treated with injection dexamethasone (Group-A) and other 15 were treated with oral prednisolone (Group-B). Random sampling method was followed. A detailed history was taken from the patient. In case of female, special attention was given regarding menstrual history and use of contraceptives. Clinical assessment was done at baseline, after every one week and lastly one and half months later. Clinical assessments include number of skin lesions of pemphigus, number of mucous membrane lesion of pemphigus, positive Nikolsky's sign, presence of bulla spreading phenomena and other physical examination. Laboratory assessment was done at baseline and after two weeks and at the end of six weeks information obtained from history, physical examination and laboratory investigation (Routine blood examination-Total count (TC), Differential count (DC), $\mathrm{Hb} \%$ and ESR, urine routine examination, blood sugar, blood urea, serum creatinine, liver function test, ECG, skin biopsy for histopathology and direct immunofluorescence test) were recorded in patient data sheet. Due to lack of available facility we could not done follow up histopathology and immunofluorescence test in this study.

\section{Procedure of treatment}

Thirty patients were included in this study using random number table. Fifteen patients were given injection Dexamethasone (GroupA) and fifteen patients were enrolled oral prednisolone (Group-B). First on admission we gave $5 \mathrm{mg}$ injection Dexamethasone eight hourly intravenously. It was continued until cessation of new bulla appeared. Then the dose was reduced $5 \mathrm{mg}$ twelve hourly. After gradual, improvement of patient's condition the dose was reduced to $5 \mathrm{mg}$ intravenously daily. After further improvement of patient condition we turned $5 \mathrm{mg}$ dexamethasone to equivalent dose of prednisolone which was $40 \mathrm{mg}$ (which was actually $34 \mathrm{mg}$ of prednisolone. But easier to take and remember we gave $40 \mathrm{mg}$ ). After six weeks we assessed the patient's outcome. The initial dose of prednisolone was (equivalent to 15mg dexamethasone) $100 \mathrm{mg}$ daily divided doses. It was continued until cessation of new bulla appeared. After gradual improvement, it 
was reduced 5-10mg weekly. After six weeks, we assess the patient's condition.

\section{Statistical Analysis}

All statistical analysis was done by SPSS 12 software package as mean \pm Standard deviation (SD). 95\% confidence limit was taken as level of significance. Comparison between two groups were done by unpaired ' $\mathrm{t}$ ' test and some qualitative data by 'Chisquare test. Comparison within group was done by paired 't' test. $\mathrm{P}<0.05$ was considered as a level of significance.

\section{Results}

Thirty patients of pemphigus vulgaris were enrolled in this study and of them 15 were enrolled in the injection dexamethasone group A (odd random table number) and 15 in the oral prednisolone group $B$. The age range of most of the patient of dexamethasone group was 30-39 yrs and 50$59 \mathrm{yrs}$. The age range of most of the patient of prednisolone group was 50-59 yrs and 4049yrs. The mean $\pm S D$ of ages in dexamethasone and prednisolone group were $41.60 \pm 13.271$ and $46.67 \pm 10.342$ years respectively. There is no significant $(P>0.05)$ difference of ages between the two groups. All demographic, clinical parameter were almost identical in two groups $(P>0.05$. Nikolsky's sign and bulla spreading phenomena expressed as number of patient. Table-1 showed that in Group-A, on admission and after 6 weeks, the mean $\pm S D$ number of skin lesion of pemphigus was $36.87 \pm 8.40$ and $5.27 \pm 1.624$ respectively. In Group-B, on admission and after 6 weeks, the mean $\pm S D$ number of skin lesion of pemphigus was $36.27 \pm 8.980$ and $7.73 \pm 1.007$ respectively. Significant difference was observed after 6 weeks $(P<0.001)$. Table 2 showed that in group- $A$, on admission and after 6 weeks, the mean $\pm S D$ number of mucous membrane lesion of pemphigus was $3.40 \pm 2.633$ and $\quad 1.00 \pm 0.926$ respectively. Significant difference was observed after 6 weeks $(P<0.001)$. In Group-B, on admission and after 6 weeks, the mean $\pm S D$ number of mucous membrane lesion of pemphigus was
$3.33 \pm 2.225$ and $1.87 \pm 1.246$ respectively. Significant difference was observed after 6 weeks $(P<0.001)$. In table-3, statistically significant differences of bulla spread phenomena of pemphigus were observed after 6 weeks between two groups $(P<0.05)$ but regarding Nikolski's sign, no statistically significant differences were observed between two groups. Table-4 showed that statistically significant differences of skin lesion of pemphigus were observed after 6 weeks between two groups $(P<0.05)$.

Table-1: Detection of number of skin lesion of pemphigus in both groups on admission and after 6 weeks therapy

\begin{tabular}{|c|c|c|c|}
\hline \multirow[t]{2}{*}{ Group-A } & \multirow{2}{*}{$\begin{array}{c}\text { Number of skin } \\
\text { lesion of } \\
\text { pemphigus } \\
\text { Mean } \pm \text { SD }\end{array}$} & \multicolumn{2}{|c|}{$\begin{array}{c}\text { Level of } \\
\text { significance }\end{array}$} \\
\hline & & $\begin{array}{l}\text { Paired t } \\
\text { value }\end{array}$ & $\mathrm{P}$ value \\
\hline $\begin{array}{l}\text { On admission } \\
\text { After } 6 \text { weeks }\end{array}$ & $\begin{array}{l}36.87 \pm 8.40 \\
5.27 \pm 1.624\end{array}$ & 16.861 & $<.001$ \\
\hline \multirow[t]{2}{*}{ Group-B } & \multirow{2}{*}{$\begin{array}{l}\text { Number of skin } \\
\text { lesion of } \\
\text { pemphigus } \\
\text { Mean } \pm \text { SD }\end{array}$} & \multicolumn{2}{|c|}{$\begin{array}{c}\text { Level of } \\
\text { significance }\end{array}$} \\
\hline & & \begin{tabular}{|l}
$\begin{array}{l}\text { Paired } t \\
\text { value }\end{array}$ \\
\end{tabular} & $P$ value \\
\hline $\begin{array}{l}\text { On admission } \\
\text { After } 6 \text { weeks }\end{array}$ & $\begin{array}{l}36.27 \pm 8.980 \\
7.73 \pm 1.007\end{array}$ & 14.337 & $<0.001$ \\
\hline
\end{tabular}

Table-IV: Detection of number of mucous membrane lesion of pemphigus in both groups on admission and after 6 weeks therapy

\begin{tabular}{|c|c|c|c|}
\hline \multirow[t]{2}{*}{ Group-A } & \multirow{2}{*}{$\begin{array}{l}\text { Number of } \\
\text { mucous } \\
\text { membrane } \\
\text { lesion } \\
\text { Mean } \pm \text { SD }\end{array}$} & \multicolumn{2}{|c|}{$\begin{array}{c}\text { Level of } \\
\text { significance }\end{array}$} \\
\hline & & $\begin{array}{l}\text { Paired } t \\
\text { value }\end{array}$ & $P$ value \\
\hline $\begin{array}{l}\text { On admission } \\
\text { After } 6 \text { weeks }\end{array}$ & $\begin{array}{l}3.40 \pm 2.633 \\
1.00 \pm 0.926\end{array}$ & 5.041 & $<0.001$ \\
\hline \multirow[t]{2}{*}{ Group-B } & \multirow{2}{*}{$\begin{array}{l}\text { Number of } \\
\text { mucous } \\
\text { membrane } \\
\text { lesion } \\
\text { Mean } \pm \mathrm{SD}\end{array}$} & \multicolumn{2}{|c|}{$\begin{array}{l}\text { Level of } \\
\text { significance }\end{array}$} \\
\hline & & $\begin{array}{l}\text { Paired t } \\
\text { value }\end{array}$ & $P$ value \\
\hline On admission & $3.33 \pm 2.225$ & & \\
\hline After 6 weeks & $1.87 \pm 1.246$ & 5.358 & $<0.001$ \\
\hline
\end{tabular}


Table-3: Outcome of Nikolski's sign and Bulla spread phenomena between Dexamethasone (Group-A) and prednisolone (Group-B) after 6 weeks.

\begin{tabular}{lccc}
\hline $\begin{array}{l}\text { Study } \\
\text { group }\end{array}$ & \multicolumn{2}{c}{ Nikolski's sign } & Chi-square value \\
& Positive & Negative & \\
\hline $\begin{array}{l}\text { Group A } \\
\text { Group B }\end{array}$ & 4 & 11 & $\begin{array}{c}1.292(\mathrm{P} \text { value } \\
>0.05)\end{array}$ \\
\hline $\begin{array}{l}\text { Study } \\
\text { group }\end{array}$ & $\begin{array}{c}\text { Bulla spread } \\
\text { phenomena } \\
\text { Positive }\end{array}$ & Negative & \\
\hline $\begin{array}{l}\text { Group A } \\
\text { Group B }\end{array}$ & 0 & 15 & $\begin{array}{c}\text { Chi-square value } \\
<0.05)\end{array}$ \\
\hline
\end{tabular}

Table-4: Out come of number of skin lesions and lesion of mucous membrane after 6 weeks between two groups.

\begin{tabular}{|c|c|c|c|}
\hline \multirow[t]{2}{*}{ Grouping } & \multirow{2}{*}{$\begin{array}{l}\text { No. of skin lesion } \\
\text { of pemphigus } \\
\text { (mean } \pm \text { SD) }\end{array}$} & \multicolumn{2}{|c|}{$\begin{array}{c}\text { Level of } \\
\text { significance }\end{array}$} \\
\hline & & t value & $P$ value \\
\hline Group A & $5.27 \pm 1.624$ & \multirow{2}{*}{-3.813} & \multirow{2}{*}{$<0.05$} \\
\hline Group B & $7.73 \pm 1.907$ & & \\
\hline \multirow[t]{2}{*}{ Grouping } & \multirow{2}{*}{$\begin{array}{l}\text { No. of mucous } \\
\text { membrane lesion } \\
\text { of pemphigus } \\
\text { (mean } \pm \text { SD) }\end{array}$} & \multicolumn{2}{|c|}{$\begin{array}{c}\text { Level of } \\
\text { significance }\end{array}$} \\
\hline & & t value & $P$ value \\
\hline Group A & $1.00 \pm 0.926$ & \multirow[t]{2}{*}{-2.162} & \multirow[t]{2}{*}{$<0.05$} \\
\hline Group B & $1.87 \pm 1.246$ & & \\
\hline
\end{tabular}

\section{Discussion}

In this study the age of the patients ranged from 20-69 years with mean age was in dexamethasone group $41.60 \pm 13.27$ years and prednisolone group $46.67 \pm 10.34$ years. However Toth et al found that the average age was 47.7 years ${ }^{7}$. It is important to note from this study that statistically significant improvement was evidenced in dexamethasone group in all clinical parameters i.e number of skin lesion of pemphigus, number of mucous membrane lesion of pemphigus and bulla spreading phenomena. But on Nikolsky's sign we did not find any significance difference between dexamethasone and prednisolone group after 6 weeks. These results were consistent with finding of study by Toth et al ${ }^{7}$. However in their study, the dose of dexamethasone was higher, $200 \mathrm{mg}$ daily. In another study by Amrinder et al, they included cyclophosphamide with dexamethasone in the treatment of pemphigus vulgaris. ${ }^{8}$ In this study the dose of dexamethasone was 136 $\mathrm{mg}$ daily and cyclophosphamide $500 \mathrm{mg}$ monthly. In between pulse they used oral corticosteroid (low tapering dose) and $50 \mathrm{mg}$ daily. Their follow up period was also for long duration. They found significance improvement with this therapy. Leela et al, used cyclophosphamide with dexamethasone in treatment of pemphigus vulgaris. They found complete remission in $82 \%$ of patient in their study. Their follow up period was one year $^{9}$. Harman et al used azathioprine and in some patients used methotrexate with dexamethasone. Their dexamethasone dose was also high. They found significance improvement in their study ${ }^{10}$. In our study we could not do follow up histopathology and immunofluronce Test. But in others study they found significance reduction of antibody titer in direct and indirect immunofluronce test ${ }^{11}$, 12 . Statistically we found that both injection dexamethasone and oral prednisolone were significant in early management of pemphigus vulgaris. These results furnished consistency with the finding of other study ${ }^{12}$. It appeared that injection dexamethasone and oral prednisolone had similar efficacy in the early management of pemphigus vulgaris.

\section{Conclusion}

This study evidenced that parenteral Dexamethasone could provide clinically significant benefit to patient in early management of pemphigus vulgaris. At the present time the clinicians although could depend on this therapy, but in future a study of long duration follow up of all cases is recommended to prove the efficacy of dexamethasone in early management of pemphigus vulgaris. 


\section{References:}

1. Crispian S, Stephen J, Challacombe. Pemphigus vulgaris: update on etiopathogenesis, oral manifestration and management. Crit Rev Oral Biol Med, 2002;13(5):397-408

2. Herbst A, Bystryn JC. Pattern of remission in pemphigus vulgaris. $\mathrm{J}$ am Acad Dermatol 2000;42:422-7

3. Stanley JR. Autoimmune blistering dermatoses. Wolff K, Goldsmith LA, Katz SI, Gilchrest BA, Paller AS and Leffell DJ. Fitzpatrick's Dermatology in General medicine. $6^{\text {th }}$ Edition, New York: The McGraw- Hill Companies; 2008.558-567.

4. Stephen E. Systemic corticosteroid. Wolverton. Comprehensive Dermatologic Drug Therapy, $2^{\text {nd }}$ Edition, W.B Saunders Company; 2001. 109-146

5. Victoria PW. Systemic corticosteroid. Fitzpatrick's dermatology in general medicine, $6^{\text {th }}$ Edition, New York: Mc Graw Hill Companies Publisher; 2008. 2381-2388

6. Sehgal VN. Pemphigus in India- A note. Indian J dermatol 2002;18:5.
7. Toth GG, Van de, Meer JB, Jonkman MF. Dexamethasone pulse therapy in pemphigus. J Eur Acad Dermatol Venereol.2002 Nov;16(6):562-3.

8. Amrinder J, Kanwar, Sukhjot K, Gurvinder P.T. Long term efficacy of Dexamethasonecyclophosphamide pulse Therapy in Pemphigus. Dermatology 2006; 204:228-231

9. Leela E, Kailash C, Bhol and Ahmed A.R. Analysis of Current data on the use of intravenous immunoglobulins in management of Pemphigus vulgaris. J Am Acad Dermatol 2009; 43:1049-57.

10. Carson $P$, Hemeed $A$, Razzaque $A A$. Influence of treatment on the clinical course of pemphigus vulgaris. $\mathrm{J} \quad \mathrm{Am}$ Acad Dermatol1996; 34:645-652.

11. Harman S, Albert, Black MM. Guidelines for management of Pemphigus vulgaris. British Journal of Dermatology 2003; 149:926-937.

12. Bystryn J, Steinman N. The adjuvant therapy of pemphigus; an update. Arch Dermatol 1996; 132:203-212. 